\title{
A Review on the Community Periodontal Index Treatment Needs In the Population of Saifi District, South Sorong Region, West Papua
}

\author{
Syarief Makka ${ }^{1}$, Yulitri Hapsari ${ }^{2}$ \\ \{syariefmakka@gmail.com¹, hapsari_ayi@yahoo.com²\} \\ ${ }^{1}$ Nusantara Sehat, Ministry of Health, Puskesmas Saifi, Jl. Mogei, Kampung Kayabo, Sorong Selatan, \\ Papua Barat, Indonesia. \\ ${ }^{2}$ Departement of periodontics, University of Prof. Dr. Moestopo (Beragama). Jl. Bintaro Permai III, \\ Bintaro, Pesanggrahan, RT 6/RW 1, Jakarta Selatan, DKI Jakarta 12330, Indonesia.
}

\begin{abstract}
The aim of this study was to discover the periodontal index needs in the population of Saifi District in South Sorong Region, West Papua Province. Based on the WHO, $30 \%$ of south East Asian region has a score of 3 on CPITN. Around 25, $9 \%$ of the Indonesian population have oral and dental diseases, A total of 31, $1 \%$ were treated and $68,9 \%$ still require treatment, almost $20,6 \%$ of West Papuan population also have oral and dental complaints as well. A total of 91 patients came to Puskesmas (Health Centre) Saifi, were examined. Patients were drawn from the age groups of 15 - 19 years old and 20 years and above, patients have also been drawn into male and female groups. The assessment was done using a WHO periodontal probe to examine each of the six sextants $(17-16,11,26-27,36-37,31,46-47)$. This study found that $57,1 \%$ of the District population scored 3, while 38, $5 \%$ scored 2 and 4, $4 \%$ scored 1 on Community Periodontal Index scoring criteria. Using Wilcoxon Sign Rank test, the $p$ value $=0.000$ was obtained $(\mathrm{p}<0,05)$, which indicated that both age and sex were significant towards periodontal treatment needs. It showed that most of the population needs periodontal treatment, also age and sex were a contributing factor to periodontal treatment needs on people in Saifi District.
\end{abstract}

Keywords: Community Periodontal Index Treatment Needs, Score, Age, Gender, West Papua.

\section{Introduction}

Oral health is rarely a priority for some people, though, teeth and mouth are the entry gates of bacteria which can cause disease on another part of the body. The problem of cavities is still often felt by the majority of the Indonesian population, but the health problems of periodontal tissues are still common and have not received attention from most people [1][2][3]. Globally, most children have signs of gingivitis and, among adults, the initial stages of periodontal diseases are prevalent. Using the so-called Community Periodontal Index (CPI), severe periodontitis, which may result in tooth loss, is found in 5-15\% of most populations. Based on the WHO report, Southeast Asia region has a CPI with a score of 0 by $10 \%$, a score of 1 by $0 \%$, a score of 2 by $40 \%$, a score of 3 by $30 \%$ and a score of 4 by $20 \%$. [4]

Basic Health Research 2013 had collected data on dental health status, indicators of service coverage and dental health behavior. Based on the report, 25.9 percent of Indonesians had dental and oral health problems in the last 12 months (potential demand), among them 31, 
1 percent received treatment from dental professionals (dental nurses, dentists or specialist dentists), while 68, 9 percent were not treated [5].The basic health research's data in the 2013 showed that 20, 6 percent of West Papuans had tooth and mouth problems, 33, 4 percent received treatment from dental professionals and 6.0 percent on effective medical demand [5]. The basic health research had not yet included the periodontal index treatment needs as one of the indicator in assessing the health level of one's oral cavity [5].

An examination of the periodontal index treatment needs of people in Saifi District, South Sorong Regency, West Papua, was expected to be the source of data on oral health and CPI treatment needs of the Saifi District community, providing South Sorong Regency and West Papua Province the data they have not yet gathered. This report was also expected to be the pioneer and encourage relevant parties both the District / Provincial Health Office and the Ministry of Health of the Republic of Indonesia to make the Community Periodontal Index Treatment Needs an indicator in determining the level of hygiene of the community's cavity. In order to aid the government creating the highest degree of dental and oral health possible $[5]$.

\section{Literature review \\ a. Periodontal tissue}

Periodonsium (peri $=$ around and odonto $=$ teeth) is a functional system of tissue surrounding the teeth and attaching teeth to the jawbone. The periodontal tissue includes the gingiva, periodontal ligament, cementum and alveolar bone [2]. Each of this tissue has an important role in maintaining the health and function of the periodontium [2]. Gingiva is part of the structure of the outer periodontal tissue [2] [3]. Gingiva functions as a supporting network of teeth, forming a connection with the gingival sulcus and protecting the tissue below attachment of teeth from the environment in the oral cavity [6]. Healthy gingiva is a pink, pointed, stippling surface texture, adapts well to the teeth and curves toward the apical (scalloped) to fit the contours of the tooth [3].

Alveolar bone is a hard part of the periodontal tissue where the teeth are embedded. The alveolar bone forms and supports the tooth socket [3]. Alveolar bone consists of external plates of cortical bone formed by harversian bone and compact bone lamellae, the inner socket wall of the thin and compact bone is called the alveolar bone proper as the lamina dura on radiographs and cancellous trabeculae, between these two layers, which acts as a support for alveolar bone. Alveolar bone consistently change in their internal growth and development, but the shape is more or less the same from childhood to adulthood [3].

Cementum is a calcified connective tissue that covers the dentine of the root and the insertion site of collagen fibers. cementum functions as an attachment bone and is the only special dental tissue of periodontal tissue [3]. There are two types of cementum, namely cellular and acellular [3]. The cementum portion containing the embedded cell is called the cellular or primary cementum located at $1 / 3$ of the apex. The part that does not contain cells that is planted is called the acellular or secondary cementum which is located in $2 / 3$ of the upper root. The largest cementum thickness occurs at the apex and in the furcation area [3].

The periodontal ligament is a layer of soft connective tissue that covers the root of the tooth and attaches it to the bone and tooth socket. Periodontal ligaments consist of collagen and are arranged in bundles of fibers. Collagen plays a role in the maintenance of the skeleton and tissue elasticity. The fibers of the periodontal ligament attach to one side to the cementum root and the other to the alveolar bone from the tooth socket. The periodontal ligament has five functions, which are as supportive function (maintaining and supporting teeth in a socket), 
sensory function (provides a sensory feeling to the teeth, such as a sensation of pressure and pain), nutritional function (provides nutrition to cementum and bone), formative function (builds and maintains cementum and alveolar bone in a tooth socket), resorptive function (can change the shape of the alveolar bone in response to pressure as occurs during the application of orthodontic fixed devices) [2].

\section{b. Periodontal disease}

Periodontal disease affects the supporting tissues of teeth, periodontal tissue, which is connects the teeth and bones supporting the teeth, called alveolar bone. The etiology of periodontal disease is dental plaque, followed by calculus, malocclusion, bad habit as predisposing factors and genetic, age, socio-economic, stress and gender as the risk factors $[3][6][9][10][11][12][13]$. Periodontal disease is one of the most widespread diseases in human life, the most common diseases affecting the periodontal tissues are gingivitis and periodontitis [6]. Gingivitis can be seen from clinical signs of inflammation that are confined to the gingiva and are not associated with attachment loss. The first stage of gingivitis is the initial lesion, the initial manifestation of gingivitis is vascular changes consisting of capillary vasodilation and increased blood flow. This initial change in inflammation occurs in response to the activity of microorganisms from leukocytes and continued stimulation of endothelial cells. The second stage of gingivitis, the clinical signs of erythema can be seen, caused by capillary proliferation and increased capillary rotation between the retepegs and ridge. Bleeding can also occur on probing. The third stage of gingivitis, blood vessels begin to swell and blood flow slows down, this is called localized gingival anoxemia which produces a bluish color on the red gingiva. The fourth stage, the advanced stage is the expansion of the lesion to the alveolar bone [3].

Periodontitis is defined as inflammation of the supporting tissues of the teeth caused by specific microorganisms from specific groups of microorganisms, which produce progressive damage to the periodontal ligament and alveolar bone with the formation of a pocket, recession or both. The clinical features that distinguish periodontitis from gingivitis are loss of clinical attachment. This is often accompanied by pocket formation and changes in the density and height of the alveolar bone. In certain cases, a recession from the marginal gingiva can accompany attachment loss, thus masking the progress of the disease if the measurement of pocket depth is carried out without measuring the clinical attachment level [3]. Clinical signs of inflammation such as color changes, shape and consistency and bleeding on probing, may not be a positive indicator of loss of attachment. However, sustained bleeding at each visit is proven to be an indicator of the inflammation that occurs and the potential for attachment loss at the site of bleeding. The attachment loss associated with periodontitis has shown a progression between continuous or sudden disease activity [3].

\section{c. Community periodontal index treatment needs (CPITN)}

The community periodontal index treatment index known as CPITN was developed by Ainamo et al who were members of the WHO committee in 1983. CPITN is an indicator of periodontal disease which is used to describe the level of periodontal conditions and their treatment needs in individuals in a population. The main objective of CPITN is to show the levels of the condition of the periodontal tissue starting from a healthy condition, the presence of bleeding, the presence of calculus, the condition of a shallow to deep pocket, and its treatment needs. The tool used for the examination is the WHO probe with a rounded probe tip 
$0.5 \mathrm{~mm}$ in diameter and there is a black area as the scale is in the region of $3.5-5.5 \mathrm{~mm}$ $[14][15][16]$.

Teeth examined from the six sextants amounted to 6 index teeth which included all first molars, central incisors over one region, and lower central incisors in region three. The method of measurement is all the six teeth measured using a WHO probe to determine the presence of bleeding, tartar, and periodontal pocket. The probe tip is inserted into the distal area of the gingival pocket and follows the anatomical configuration of the root surface of the tooth from distal to mesial on the labial and lingual surfaces. Record the score according to the results obtained. Only the worst part is recorded in each part. The highest score of all sextant is used to determine the score of treatment needs $[14][15][16]$.

Table 1. Score criteria

\begin{tabular}{|c|c|c|}
\hline Score & Periodontal Status & Periodontal Therapy \\
\hline 0 & Healthy. & No treatment needed. \\
\hline 1 & Bleeding on probing. & Oral hygiene instruction \\
\hline 2 & $\begin{array}{l}\text { Bleeding on probing, but the black } \\
\text { part of the probe is still visible }\end{array}$ & $\begin{array}{l}\text { Oral hygiene instruction and } \\
\text { scaling }\end{array}$ \\
\hline 3 & $\begin{array}{l}\text { Periodontal pocket } 4-5 \mathrm{~mm} \text { depth, } \\
\text { gingival margin is parallel with the } \\
\text { black part of the probe. }\end{array}$ & $\begin{array}{l}\text { Oral hygiene instruction and } \\
\text { scaling, root planing }\end{array}$ \\
\hline 4 & $\begin{array}{l}\text { Periodontal pocket }>6 \mathrm{~mm} \text {, the black } \\
\text { part of the probe is not visible }\end{array}$ & $\begin{array}{l}\text { Oral hygiene instruction, scaling } \\
\text { and complex treatment }\end{array}$ \\
\hline
\end{tabular}

\section{Methods}

This research is a Descriptive Observational with Cross Sectional design. Data retrieval were done directly by research's subject to obtain CPTIN score. This research was done in Kayabo and Sayal village, Saifi district, South Sorong regency, West Papua in 2018. The population were the natives who live in Kayabo and Sayal village, South Sorong regency. The subject were the patients who came to Saifi Health Centre. Subject data retrieval was done by using random sampling method which could resemble the population. Obtained data will be served descriptively using the calculation of SPSS to acquire the sum and presentation of the results. The results will be served in narration and table.

\section{4. $\quad$ Result}

This research was conducted at Saifi Health Center, South Sorong Regency, West Papua, against 91 patients, aimed at finding out the periodontal index treatment needs of the community. The following will be presented by tables and charts of the distribution of frequency of age, gender, characteristics of the patient's gum color, habit of consuming betel nut, gum bleeding and periodontal treatment needs. 
Table 2. Frequency distribution

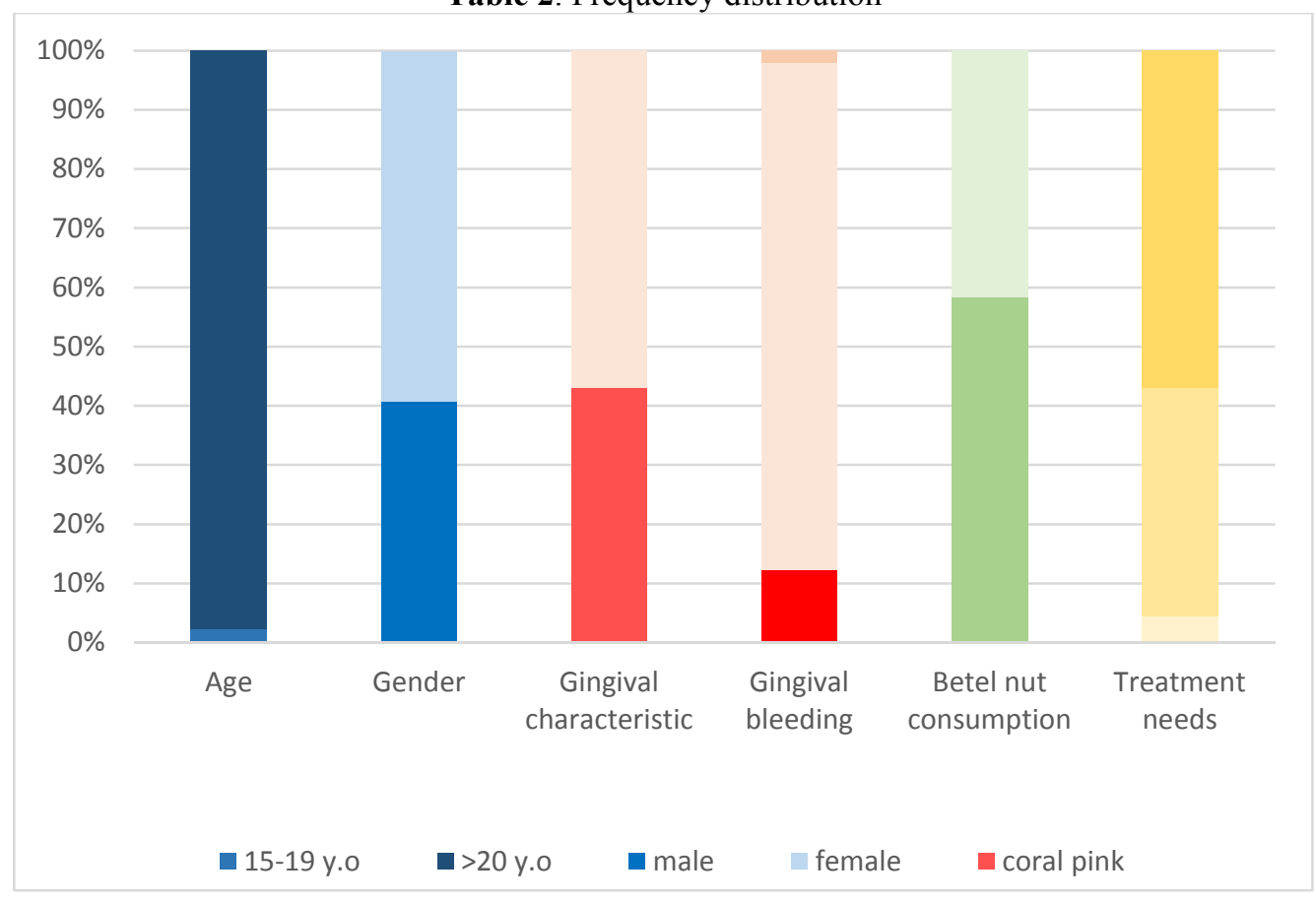

Based on the table and chart above, it can be explained that the CPI examination was conducted on 91 people, 2 people aged 15-19 years old and 89 people aged over 20 years old with a percentage of $2,2 \%$ and $97,8 \%$, respectively. While for the comparison of sex as many as 37 people were male with the percentage of $40,7 \%$ and 54 people of female sex with a percentage of $59,3 \%$. Subsequent data showed examination of coral pink gingival characteristics with bright pink gum color features and stippling of $42,9 \%$ and pale pink gingiva with no stippling characteristics with fibrotic pale gum color of 57, 1\%. At a gingival bleeding examination of $12,1 \%$ of the gums had bleed and the presence of stimuli, amounting to $85,7 \%$ said they had never experienced bleeding and 2, 2\% said they did not know. As many as $58,2 \%$ of respondents said they consumed areca nut, while $41,8 \%$ said they did not consume areca nut. Periodontal index treatment needs with a score of 1 requiring DHE and $\mathrm{OHI}$ of $4,4 \%$, score 2 with treatment needs in the form of $\mathrm{OHI}$, scaling and polishing of 38 , $5 \%$ and score 3 with treatment needs in the form of OHI, scaling, polishing and root planing of $57,1 \%$. The following are the results of the normality test:

Table 3. Normality test

\begin{tabular}{lcc}
\hline & Variable & Shapiro-Wilk \\
\hline Age & 0,00 \\
Gender & 0,00 \\
\hline
\end{tabular}

Data are normally distributed $=p>0.05$ 
The results of the normality test using the Shapiro-Wilk method showed the results of $p$ value of 0.00 ( $\mathrm{p}$ value $<0.05$ ) which means that the data are not normally distributed, and therefore further testing of non-parametric data. Using the Wilcoxon Sign Rank test method, the results obtained are as follows:

Table 4. Wilcoxon sign rank test

\begin{tabular}{lc}
\hline & Asymp. Sig. (2 tailed) \\
Treatment needs, gender, age & .00 \\
\hline
\end{tabular}

The results of the non-parametric test method Wilcoxon Sign Rank test showed the results of $\mathrm{p}$ value $0,00(\mathrm{p}<0,05)$ that there are significant gender and age influences on periodontal index treatment needs.

\section{Discussion}

This study was conducted to describe the periodontal index treatment needs of the people of Saifi District, South Sorong Regency, West Papua. This study was conducted on 91 patients who came to Saifi Health Center, Respondents were divided into two groups, namely the age group 15-19 years and age $>20$ years. This study used an observational descriptive method with a cross sectional design. CPI measurements use WHO periodontal probes by examining teeth in each sextant, and then given a CPI assessment score (TN 0, TN 1, TN 2, TN 3 and TN 4) [14]. In this study more respondents were female than male. There are $40,7 \%$ of male respondents and $59,3 \%$ of female respondents, as many as $97,8 \%$ of respondents are those of 20 years and above. Respondents aged 15-19 years are 2, 2\%, this occurred generally because they have worked in fields, forests or fishing to find food, therefore patients who came were dominated by people aged of 20 years and over and women. This condition was common in the Saifi District where the socio-economic conditions were still low. In addition, awareness of maintaining poor oral hygiene and the habit of consuming betel nuts were still present in most of the natives.

Generally the Saifi District people consume betel nut $(58,2 \%)$ so that the color of their teeth became yellow and there were stains attached to the surface of their teeth. Consuming betel nut was a natural habit in the region, besides, there were many betel nut trees planted by the people, it also became a tradition of local people, this was compounded by the many people of Papua who were not used to keep their dental and oral hygiene maintained. According to Inns and Low (2011) which revealed that consuming betel nut in South Asia and Southeast Asia was common, the highest prevalence was found in the population in the Pacific Islands with consumption rates reaching $72 \%$ for men and $80 \%$ for women [17]. Besides consuming areca nut most people also consume cigarettes, both men and women.

Smoking habits became one of the predisposing factors for the poor oral hygiene of the Saifi District community. Both men and women in Saifi District consumed cigarettes, ranging from cigarettes made from dried leaves, cigarettes made of paper or cigarettes which were generally sold on the market. This certainly can affect the condition of soft and hard tissue in the oral cavity. Smoking, which can be called a major risk of periodontal disease, has a negative effect on the user's defense system locally and systemically. Locally, the vasoconstriction effect of nicotine in cigarettes flowing in blood vessels causes a reduction in cells and red blood flow, the amount of oxygen and nutrients carried to the gingiva [18]. After research by Suratri and Notohartojo (2016) lack of oxygen and impaired immune response are 
the results of narrowing of blood vessels, this can create an environment that can support the proliferation and growth of the bacteria that cause periodontal disease [19].

On examination of gingival bleeding performed on male and female respondents who came to Saifi Health Center showed a result of $85,7 \%$ of respondents did not have gingival bleeding at the time of the CPI examination. The results obtained from the examination of gingival characteristics in men and women were $57.1 \%$ pale white, without stippling and $42.9 \%$ colored coral pink with stippling. Oluwole and Elizabeth (2010) suggest that the color of healthy gingiva varies from pale pink, coral pink, light brown and dark brown, depending on the variation of each individual. This gingival color variation depends on the amount of melamine pigment in the epithelium, the degree of keratinization of the epithelium, vascularization and fibrous tissue on the basis of connective tissue pigmentation which is small in white people and can be found as brown, dark blue in African or Asian people. In attached gingiva generally colored coral pink and has a texture like orange peel, while alveolar mucosa is dark blue-red which is smooth and slippery. There is a definite relationship between color variations in the oral cavity and external pigmentation in white, black and Asian people [20].

As many as $57,1 \%$ of respondents both male and female and over 20 years old received a TN 3 score and needed treatment in the form of DHE, OHI, scaling, polishing, root planing and curettage, while $38,5 \%$ of respondents were aged men and women 20 years and above required periodontal treatment in the form of scaling and polishing. The periodontal disease suffered by the Saifi District community may be caused by various predisposing factors described earlier. According to Alam et al there is evidence to support that the prevalence of periodontitis is greater in men than women, the reason caused by poor oral hygiene, awareness and dental visits compared to other genetic factors. Another important factor to consider is that women still have various periodontal problems due to hormonal fluctuations. Therefore, the results of treatment plans for periodontal disease based on gender differences are unpredictable, because the patterns of disease development differ between men and women [21].

The results of the non-parametric test of the Wilcoxon Sign Rank test method showed significant results between gender and age on periodontal treatment needs. This can be interpreted that the majority of both men and women domiciled in the Saifi District need periodontal treatment. As with age, most Saifi District residents aged 20 years and above need periodontal treatment. Based on research conducted by Mahajani et al (2016), the results obtained with a high percentage (64\%) in the population, these results are in accordance with various studies that make observations in populations in rural areas. A strong relationship between age may follow the results of increasing effects of the disease rather than reduced resistance in the elderly [22].

\section{Conclusion}

The results showed that generally the population of Saifi District need periodontal treatment (score 3), and the treatment needed are DHE, OHI, scaling, polishing and root planning. Various predisposing factors, such as smoking, poor oral hygiene, consumption of betel nut, stress, socio-economic and age and gender can contribute to the progression of periodontal disease. 


\section{References}

[1] Pusat Data dan Informasi Kemenkes RI. 2014; 1.

[2] Gehrig and Willmann. Foundations of Periodontics for the Dental Hygienist $2^{\text {nd }}$ Edition. Lippincott William and Wilkins. 4-11.

[3] Carranza, Newman, Takei, Klokkevold. Carranza's Clinical Periodontology $10^{\text {th }}$ Edition. Saunders Elsevier. 2006; 46-83.

[4] The World Oral Health Report. 2003; 4-6.

[5] Riskesdas. Badan Penelitian dan Pengembangan Kesehatan. Kemenkes RI. 2013; 110 119.

[6] Megananda HP, Eliza H, Neneng N. Ilmu Pencegahan Panyakit Jaringan Keras dan Jaringan Pendukung Gigi. Jakarta. EGC. 2010. 26-39.

[7] Eley BM, Soory M, manson JD. Periodontics $7^{\text {th }}$ Edition. Edinburgh. Saunders Elsevier. 2010.

[8] Avery JK, Chiego Jr. DJ. Essentials of Histology and Embryology Clinical Approach $3^{\text {rd }}$ Edition. Chicago. Elsevier. 2009; 146-64.

[9] Noor, E. Al-Bayaty, Fouad. A review on Predisposing and modifying factors of periodontal disease. Journal of advanced medical research. 2015; 5-23.

[10] Rose, Louis F, and Robert J Genco. Periodontal Medicine. London: B. C. Decker. Inc, 2000.

[11] Arun et al. Influence of Literacy and Socioeconomic Status on Awareness of Periodontal Disease. Medico Research Chronicles. 2015.

[12] Avasthy, P. Risk Factors for Periodontal Diseases. Journal of Applied Dental and Medical Sciences. 2015.

[13] Alam, Nazish. Et al. Gender Basis of Periodontal Disease. Indian Journal of Basic \& Applied Medical Research; 2012.

[14] WHO Technical Report Series. Epidemiology, Etiology, and Prevention of Periodontal Disease. Geneva. 1978.

[15] Preshaw, Phillip. Detection and Diagnosis of Periodontal Conditions Amenable to Prevention. BMC Oral Health. Cape Town. 2014

[16] WHO. Oral Health Survey Basic Methods $5^{\text {th }}$ Edition. 2013

[17] Binns, Colin. Low, Wah Yun. Betel Chewing and Public Health. Asia-Pasific Journal of Public Health. 2011.

[18] Saribas, Ebru et al. Determination of Periodontal Status and Smoking Habits with CPITN Index. International Dental Research. 2017.

[19] Suratri, Made Ayu. Notohartojo, Indirawati Tjahja. Smoking as A Risk Factor of Periodontal Disease. Health Science Journal of Indonesia. 2016.

[20] Oluwole, Dosumu. Elizabeth, Dosumu. Gingival Tissue Color Related with Facial Skin and Acrylic Resin Denture base Color in a Nigerian Population. African Journal od Biomedical Research. 2010.

[21] Alam, Nazish et al. Gender Basis of Periodontal Disease. Indian Journal of Basic \& Applied Medical Research. 2012.

[22] Mahajani, Monica et al. Assessment of Periodontal Health Status and Treatment Needs in Rural Population of the Central Maharashtra; A Cross Sectional Study. Journal of International Oral Health. 2016. 